\title{
VAD MANDATPERIODEN GÖR MED FULLMÄKTIGELEDAMOTEN: STÄRKS POLITISKT SJÄLVFÖR- TROENDE ELLER BLIR MAN DESILLUSIONERAD?
}

Gissur Ó Erlingsson, Centrum för kommunstrategiska studier, ISAK, Linköpings universitet E-post I gissur.erlingsson@liu.se

Richard Öhrvall, Avdelningen för statsvetenskap, IEI, Linköpings universitet och Institutet för Näringslivsforskning, IFN, Stockholm E-post I richard.ohrvall@liu.se

Vad gör erfarenheten av att aktivt delta politiskt med en individs syn på sig själv som politisk varelse och på dennes tillit till demokratin? Inom den deltagardemokratiska skolan kan man ibland skymta en hoppfull bild av vad politiskt deltagande förmår göra med individs tilltro till det egna politiska självförtroendet (engelska: political efficacy ${ }^{1}$ ). För Rousseau var en av huvudpoängerna med politiskt deltagande intimt knutet till de psykologiska effekter deltagandet antogs ha för individen, det Jacobsson (1999: 164) kommit att kalla "demokratins lärandefunktion". Tanken är att när individer ges möjligheten att delta politiskt ökar sannolikheten att han eller hon fördjupar sitt engagemang ytterligare - vi får vad man kan kalla

(C) 2016 Gissur Ó Erlingsson och Richard Öhrvall. Detta är en Open Access artikel distribuerad under CC-BY-NC som innebär att du tillåter andra att använda, sprida, göra om, modifiera och bygga vidare på ditt verk, men inte att verket används i kommersiella sammanhang. http://dx.doi.org/10.15626/sj.20163102 
för "deltagandets positiva spiral" (jfr Pateman 1970; Thompson 1970). Finkel (1987: 441) har sammanfattat traditionens huvudpoäng på följande sätt:

These 'participatory' theorists ... believe that participation is intrinsically beneficial, because it develops many positive, democratic character traits, such as community-mindedness, political selfcompetence, and satisfaction with decision-making structures, institutions, and outputs (vår kursiv).

Frågan är vilket stöd dessa teoretiska förutsägelser får i data. Om man ska studera detta, är Sverige ett särskilt intressant fall att rikta blickarna mot. Sedan 1990-talet har den svenska kommunsektorn strävat efter att engagera medborgare i olika typer av deltagardemokratiska innovationer, eller "lokala demokratiexperiment" som Montin (1998: 8) kallat satsningarna (jfr Jarl 2003). Resultaten av de analyser som gjorts av den här typen av medborgarriktade demokratisatsningar är emellertid inte alltför upplyftande för tesen om deltagandets positiva spiral. $^{2}$ I en av de sällsynta empiriska analyserna av demokratisatsningarnas effekter på medborgarna, når Gilljam och Jodal (2005: 26) slutsatsen att:

[k]ommunernas satsningar på demokratiutveckling har inte resulterat $\mathrm{i}$ en mer vital demokrati med mer aktiva och tillitsfulla medborgare. Trots en lång rad olika analyser har vi inte funnit några belägg för att kommunerna har lyckats administrera fram en bättre fungerande demokrati. De kommunala demokratisatsningarna måste tvärtom bedömas som misslyckade.

Fast, kanske är det här fel typ av engagemang att studera om man vill ge teorin om "deltagandets positiva spiral" en ärlig chans att infria förväntningar om ökad självtillit och tilltro till demokratin som följd av att delta i kollektivt beslutsfattande? Kanske gör vi det allt för svårt för hypotesen när vi studerar centralt dirigerade demokratisatsningar, där människor i första hand går in för att påverka något i närområdet, för att kanske framför allt gynna sig själv eller sina närmaste, med premissen att det är en förhållandevis kortsiktig engångsinsats?

Måhända inte helt $\mathrm{i}$ linje med deltagardemokraternas ursprungliga intentioner, men ett alternativt sätt att studera effekter av politiskt deltagande är att rikta in sig på sådant deltagande kräver ett långsiktigt engagemang och ett brett ansvarstagande. Istället för att studera människor som går från inaktivitet till deltagande på något avgränsat område skulle det då här vara intressant att se närmare på individer som tar klivet från att vara så kallade "postgiro-" eller "gräsrotsmedlemmar" i ett politiskt parti, till att bli förtroendevalda politiker. Också i detta avseende är nämligen Sverige ett väl anpassat fall att titta närmare på. En bestämd typ av politiskt deltagande som torde vara lovande att studera ur denna aspekt, bland annat på grund av hur utbrett det är i Sverige - liksom för att det är underutforskat - rör därför individer som engagerar sig inom ramarna för de politiska partierna i svensk kommunpolitik (jfr Erlingsson m.fl. 2012).

Det är nämligen väldigt många individer som är engagerade på detta sätt. År 2015 uppgick de förtroendevalda i svenska kommuner till cirka 36800 personer, där endast omkring 1300 av dessa är hel- eller deltidsarvoderade (SCB 2015), medan den överväldigande delen med andra ord är fritidspolitiker. Så, vad erfarenheten av att bli och vara förtroendevald gör med dessa människor, står i centrum för föreliggande studie. Mer precist - och kopplat till den 
deltagardemokratiska traditionens antaganden om "deltagandets positiva spiral" - är vår övergripande fråga vad erfarenheten av att delta på detta sätt gör med de nya kommunpolitikernas politiska självförtroende samt deras tillit till demokratin.

\section{Tidigare forskning: resultaten pekar åt olika håll}

Vad vet vi då från tidigare undersökningar? Det saknas i stor utsträckning forskning som haft denna frågeställning - den politiska erfarenhetens inverkan på politiskt självförtroende och tilltro till demokratin - som primärt fokus i det svenska sammanhanget. Men ett par relevanta studier är värda att se närmare på, även om frågan om hur erfarenheten av att vara förtroendevald inte står i omedelbart centrum för studierna.

Exempelvis lät Karlsson (2001) nya politiker utvärdera hur de själva hade upplevt sin första tid som förtroendevald genom att be dem relatera sina erfarenheter till de förväntningar man (trodde sig minnas att man) hade innan uppdraget. Karlsson ställde frågan om det var lättare eller svårare för dem, jämfört med förväntningen, att hantera arbetsbelastningen som följde med uppdraget. Karlsson fann bland annat att yngre individer och kvinnor överlag blev mer negativt överraskade jämfört med äldre respektive män, både vad beträffar arbetsbelastningen och vad gäller arbetets svårighetsgrad. Begränsningarna med Karlssons studie är emellertid det faktum att han enbart riktade sin enkät till de som var nya efter valet 1998 liksom att resultaten vilar på respondenternas minnesbilder av sina förväntningar. Föreliggande studie försöker komma runt båda dessa problem genom den dels 1) har med en kontrollgrupp av erfarna politiker för att se om infriade eller icke-infriade förväntningar på uppdraget är något unikt för de nya eller om de också speglas i de mer erfarnas upplevelser, dels 2) bygger på en paneldesign med en första datainsamling innan den aktuella mandatperioden inleds, vilket gör att vi undviker potentiella fallgropar med att be våra respondenter försöka minnas vilka förväntningar de hade innan uppdraget påbörjades.

Utöver Karlssons undersökning finns det ett par tidigare undersökningar som, åtminstone indirekt eller mellan raderna, berört frågan om politikers erfarenheter av att vara förtroendevald. Aspekten har nämligen funnits med i bakgrunden i närmast alla studier som analyserat förtroendevalda som har hoppat av sitt uppdrag i förtid. Några av studierna tangerar i delar Karlssons kanske något nedslående slutsatser. Just nya politiker är nämligen överrepresenterade bland avhopparna, och exempelvis konstaterade en studie på området att avhoppen "kan och bör ses som ett tecken på att vår demokrati inte fungerar fullt ut" (Institutet för lokal och regional demokrati 2006), medan en annan nådde slutsatsen att brister i interndemokrati och toppstyre inom partierna inverkar på avhoppsbeslutet (Hassis m.fl. 2009). Vad som antyds i båda dessa analyser är att erfarenheten av att komma in som ny i politiken för med sig en hel del negativ återkoppling som bidrar till avhopp.

Mediebilden av avhopp och politikens villkor stärker också en sådan dyster bild av nykomlingarnas erfarenheter av förtroendeuppdrag. Exempelvis har statsvetare som intervjuats för rapportering om förtida avhopp nått följande slutsatser: 
De omständliga arbetsformerna, trögheten i organisationen och känslan av att inte kunna påverka skrämmer bort unga och kvinnor från politiken (SVT 2006-02-13).

För många som trots allt påbörjar sitt politiska uppdrag, kan det vara en chock hur pass mycket tid och energi arbetet ändå tar (SVT 2015-01-13).

Utifrån sådana forskningsresultat och resonemang kring nyhetsrapportering, skulle man kunna dra slutsatsen att erfarenheten av att vara politiskt aktiv som lokalt förtroendevald ger upphov till en känsla av otillräcklighet, att det innebär en överbelastning sett till ens initiala förväntningar på uppdraget, att man inte riktigt blir lyssnad på, och därmed att avhoppen signalerar missnöje med den lokala demokratins institutioner.

Emellertid ska man vara medveten om att en sådan bild av avhoppen inte har fått stå helt oemotsagd. I rapporten Politikens villkor, tecknade författarna till föreliggande uppsats (Erlingsson och Öhrvall 2010) en till stora delar alternativ bild av avhoppen. Överlag uppgav nämligen respondenterna $\mathrm{i}$ den studien att avhoppen $\mathrm{i}$ huvudsak inte berodde på dåliga erfarenheter av politiska processer eller strukturer, utan av förhållanden i privatlivet (framför allt att man hade flyttat från kommunen, alternativt att man hade upplevt problem att kombinera uppdraget med arbetsliv och familjeliv). En stor andel av avhopparna (81 procent) uppgav dessutom att de, trots avhoppet, hade haft en mycket eller ganska positiv syn på tiden i kommunpolitiken. Rapporten landade därför in konklusionen att när "larmrapporter om demokratins hälsotillstånd tenderar att stjäla utrymme i den offentliga debatten, är det viktigt att uppmärksamma den här typen av nyanserade och mer hoppfulla resultat" (Erlingsson och Öhrvall 2010: 8).

Utöver detta, fann vi - i en mer sentida studie av nya politiker - flera andra upplyftande saker (Erlingsson m.fl. 2015). Bland annat konstaterades att de flesta som kandiderade i 2014 års val för första gången upplevde att deras politiska engagemang bemöttes positivt av familj, släkt, vänner, arbetskamrater, grannar och av andra förtroendevalda. Dessutom var respondenterna påfallande nöjda med de interndemokratiska procedurerna före och efter valet avseende hur valsedlarna hade satts samman, liksom hur fördelningen av uppdrag hade gått till. Detta gällde såväl avseende vilket uppdrag de själva fick som när de fick bedöma genomskinligheten i processerna.

Dessa litet mer upplyftande resultat bekräftar i allt väsentligt resultat om förtida avhoppare som Nielsen (2001) presenterade runt millennieskiftet. Det finns fler resultat i Nielsens studie som mer eller mindre går i linje med de förväntningar som de refererade deltagardemokratiska teoretikerna vi återgav inledningsvis har. Exempelvis fann Nielsen att betydligt fler av de nya politikerna fick ökat förtroende för lokalpolitiker i allmänhet sedan man fått sitt uppdrag (1/3), jämfört med dem vars förtroende minskade (1/5). Också Fredrikssons (2001) kvalitativa intervjustudie fann ljuspunkter av detta slag, där han redogör för hur de nya politikernas tilltro till det politiska systemet förändrades efter att ha blivit förtroendevald: "överlag har [det] skapats en större och mer nyanserad förståelse för det politiska arbetet". 
Det finns en ytterligare aspekt här att beakta och det medges att det inte direkt har med politiskt självförtroende eller nöjdhet med demokrati att göra. Men, just Fredriksson (2003) har med kvalitativa metoder lanserat resultat som åtminstone delvis är relevanta för våra intressen. Enligt Fredriksson har det nämligen över tid kommit att bli en oskriven regel för kommunpolitiker att stå bakom de gemensamma partipolitiska ståndpunkterna, oavsett vad man själv eller vad man uppfattar att ens väljare tycker (se också Bäck 2000). Det betraktas, enligt Fredriksson, vara ett stort snedsteg av den enskilda fullmäktigeledamoten att inte följa partilinjen. Mycket riktigt visar också mer extensiva enkätstudier att kommunernas förtroendevalda tycker att en av deras viktigaste uppgifter är att föra fram partiets åsikter (Sveriges kommuner och landsting 2005: 25), och alltså inte främst att agera efter eget omdöme eller enligt väljaropinionen. En fråga som aktualiseras och som nog är relevant för vårt ärende, är om partilojaliteten är en egenskap man som ny politiker redan har med sig när man kommer in i fullmäktige för första gången, eller om det eventuellt är något man förvärvar eller socialiseras in i under fullmäktigeperiodens lopp. Detta skulle i så fall kunna ge oss ledtrådar om huruvida erfarenheten av att vara förtroendevald påverkar synen på den egna representantrollen, och därmed också inverkar på den egna demokratisynen, ju längre mandatperioden går.

\section{Undersökningens övergripande syfte}

För att rekapitulera: i den deltagardemokratiska litteraturen återfinns förutsägelser om att politiskt deltagande och engagemang stärker de deltagande individernas politiska självförtroende samt ökar tilltron till hur de demokratiska institutionerna fungerar. Om än med vissa metodologiska begränsningar, och inte direkt med frågan om "politiskt självförtroende" som forskningsfokus, pekar empiriska studier av svenska kommunpolitikers erfarenheter åt litet olika håll och ger sålunda litet olika förväntningar på vad vi ska finna. Några tycks mena att lusten till deltagande och engagemang avtar som följd av tidskrävande uppdrag samt tröga och svårforcerade organisationer, medan andra uppmärksammat att de allra flesta upplever tiden $\mathrm{i}$ fullmäktige som positiv och att till exempel förtida avhopp från kommunfullmäktige främst ska förklaras i termer av förändringar i privatlivet snarare än med hänvisning till politiska förhållanden. De metodologiska begränsningar dessa studier delar, är att de bygger på respondenternas minnen av hur tiden i fullmäktige var och vad som påverkade deras beslut att hoppa av samt bara har undersökt nya politiker. Föreliggande studie använder sig av en paneldesign som också inkluderar mer erfarna politiker för att komma runt de begränsningarna.

Mot denna bakgrund är syftet med föreliggande uppsats att försöka utröna vad erfarenheten av att bli invald och under ett par år vara en del av den politiska verkligheten som förtroendevald, gör med fullmäktigeledamöters politiska självförtroende och tillit till demokratins procedurer i hemkommunen. Vi kommer därtill vidare att undersöka om deras egen syn på representantrollen påverkas. Analyserna baseras på data från en panelundersökning riktade till kandidater i 2014 års val till kommunfullmäktige, vilken innefattar en mätpunkt före valdagen, och en mätpunkt ungefär halvvägs in i mandatperioden. 


\section{Data och design}

Föreliggande studie bygger på en undersökning av ett slumpmässigt urval av de personer som kandiderade i 2014 års kommunfullmäktigeval. Undersökningen är en panelstudie i vilken vi har genomfört en första datainsamling före 2014 års val, en andra i början av 2015 och en tredje under våren och sommaren 2016. Urvalet är ett stratifierat klusterurval där vi slumpmässigt valt ut 30 kommuner stratifierat efter kommuntyp, enligt Sveriges Kommuner och Landstings klassificering. Samtliga 5360 personer som kandiderade till kommunfullmäktige i dessa 30 kommuner ingår i vårt urval. Uppgifter om vilka som kandiderade har vi erhållit från Valmyndigheten. Svar från dessa kandidater har samlats in via webbenkäter (tillvägagångssättet beskrivs närmare nedan).

Resultaten som presenteras här baseras på undersökningens första och tredje enkätomgång. Den första omgången inleddes den 14 augusti 2014 och avslutades strax före valdagen den 14 september 2014 och den tredje omgången inleddes 16 maj 2016 och avslutades den 31 augusti samma år. Detta innebär att tiden mellan de två undersökningsomgångarna kan variera mellan 20 och 24 månader. Något förenklat kan det beskrivas som att vi jämför politikernas svar strax innan valdagen 2014 med deras svar halvvägs in i mandatperioden.

I den första undersökningsomgången fick vi tag på e-postadresser till 2767 personer av de 5360 kandidater som ingick i vårt urval, det vill säga till 52 procent av dem. Till dessa personer skickades en inbjudan till att besvara en webbenkät. Vi skickade ut ett brev till de resterande 2593 kandidater som ingick i vårt urval, men för vilka vi inte lyckades få uppgift om epostadress. Brevet presenterade undersökningen och innehöll en länk till webbenkäten och uppgifter om lösenord och inloggningsuppgifter. Den första undersökningsomgångens enkät besvarades av 2034 personer, vilket ger en svarsandel om 38 procent. Bland dem som vi kontaktade via e-post svarade 1380 av 2767, vilket ger en svarsfrekvens om 50 procent.

Den tredje undersökningsomgången gick ut till 3583 personer därav 2073 som svarat i någon av de två tidigare omgångarna och 1510 som inte svarat tidigare. Vi fick totalt sett in 1177 svar, vilket motsvarar en svarsandel om 22 procent av samtliga 5360 kandidater och 33 procent av dem som fick e-postutskicket och därmed hade möjlighet att svara. I den här studien fokuserar vi främst på de 615 kandidater som besvarade både omgång 1 och omgång 3 och som har förtroendeuppdrag i kommunfullmäktige, kommunstyrelse eller nämnder.

Det bör nämnas att det totala bortfallet för undersökningen är stort, även om det är i nivå med eller till och med lägre - än för många andra liknande undersökningar. Om vi utifrån de uppgifter vi har om samtliga som kandiderade i 2014 års val, jämför de som har besvarat undersökningen med dem som inte gjort det, ser vi inte några stora eller systematiska skillnader som föranleder oss att tro att undersökningens resultat skulle bli missvisande med vårt urval. Vi använder dessutom vikter för att justera representativiteten utifrån uppgifter om parti och kommun, vilket till viss del kompenserar för bortfallet. 
Panelansatsen har ett antal fördelar, framför allt att vi på ett mer träffsäkert sätt kan studera förändringar över tid än vad vi menar att de ovan refererade studierna förmått göra, som främst förlitat sig till respondenternas minnesbilder. Detta gäller i synnerhet förväntningar på förtroendeuppdraget: då vi har en insamlingsomgång innan mandatperioden tar vid kan vi mäta vilka förväntningar kandidaterna säger sig ha. Detta är att föredra mot frågor om förväntningar i efterhand, vilka kan vara medvetet eller omedvetet färgade av erfarenheter. Eftersom vi studerar samtliga kandidater i de 30 slumpmässigt utvalda kommunerna innefattar vårt urval både kandidater som är nya i politiken och sådana som är mer erfarna. Detta innebär att vi kan ställa förändringar över tid mot de olika grupperna. Som ny i politiken betraktar vi dem som i första enkätomgången uppgav att de aldrig har varit ledamot i kommunfullmäktige, kommunstyrelse, kommunal nämnde eller kommunal bolagsstyrelse. Av dem som besvarade både enkätomgång 1 och enkätomgång 3 var ungefär var fjärde respondent att betrakta som ny, med denna definition.

\section{Resultat}

Vårt övergripande intresse här rör alltså hur erfarenheten av politiskt deltagande påverkar individer som kommer in som nya $i$ politiken. Med inspiration hämtad från den deltagardemokratiska traditionen och dess förutsägelser om vad som händer när man dras in deltagande och kollektivt beslutsfattande, är vi främst intresserade av dels om erfarenheten inverkar på tilltron till det egna politiska självförtroendet på ett positivt sätt, dels om erfarenheten inverkar på förtroendet till demokratin på ett positivt sätt.

För att kort rekapitulera en grundläggande metodpoäng, baseras våra analyser på förtroendevalda kommunpolitiker och vi är i första hand nyfikna på de individer som kandiderade till politiska uppdrag för första gången inför valet 2014. Men, för att ha en jämförelsegrupp, kontrasterar vi dem med de kandidater som inte kandiderade för första gången i valet 2014 - och därmed kan ses "erfarna", enligt vår definition här - för att se också om deras politiska självförtroende och tilltro till demokratin också påverkas under mandatperiodens lopp. I denna analys intresserar vi oss bara för den förändring vi ser från vår första materialinsamlingsomgång, till den tredje materialinsamlingsomgången; det vill säga, grovt uttryckt, från strax före valet 2014 och i mitten av mandatperioden.

\section{Förväntningar kontra erfarenhet: ändras det politiska självförtroendet?}

I syfte att mäta det politiska självförtroendet, ställde vi i både första och tredje enkätomgången en rad frågor för att försöka fånga upp saker som vi argumenterar kan betraktas som aspekter av detta. Vi har här avgränsat urvalet av respondenter till att uteslutande handla om personer som innehar ett förtroendeuppdrag halvvägs in i mandatperioden (det vill säga, är ledamot $\mathrm{i}$ kommunfullmäktige, kommunstyrelse och/eller i någon nämnd). Den första frågan rörde i vilken grad respondenterna trodde att de, genom kommunpolitiken, kommer att kunde få igenom en sakfråga. Resultatet redovisas i tabell 1. 
Tabell 1: Tilltron att få igenom sakfrågor?

\begin{tabular}{|c|c|c|c|c|c|c|c|c|c|}
\hline \multirow{3}{*}{$\begin{array}{l}\text { Få igenom } \\
\text { en } \\
\text { sakfråga? }\end{array}$} & \multirow{2}{*}{\multicolumn{3}{|c|}{$\begin{array}{l}\text { Omgång } 1 \\
\text { Ny i } \\
\text { politiken? }\end{array}$}} & \multirow{2}{*}{\multicolumn{3}{|c|}{$\begin{array}{l}\text { Omgång } 3 \\
\text { Ny i } \\
\text { politiken? }\end{array}$}} & \multirow{2}{*}{\multicolumn{3}{|c|}{$\begin{array}{l}\text { Förändring } \\
\text { Ny i } \\
\text { politiken? }\end{array}$}} \\
\hline & & & & & & & & & \\
\hline & Nej & $\mathrm{Ja}$ & Totalt & Nej & $\mathrm{Ja}$ & Totalt & Nej & $\mathrm{Ja}$ & \\
\hline $\begin{array}{l}\text { Hög/ganska } \\
\text { hög grad }\end{array}$ & 81,1 & 62,4 & 77,3 & 64 & 45,8 & 60,2 & $-17,1$ & $-16,6$ & $-17,1$ \\
\hline $\begin{array}{l}\text { Låg/ganska } \\
\text { låg grad }\end{array}$ & 18,1 & 32,1 & 21 & 35,5 & 51,7 & 38,9 & 17,4 & 19,6 & 17,9 \\
\hline Vet ej & 0,8 & 5,4 & 1,8 & 0,5 & 2,5 & 0,9 & $-0,3$ & $-2,9$ & $-0,9$ \\
\hline Totalt & 100 & 100 & 100 & 100 & 100 & 100 & - & - & - \\
\hline Antal obs. & 493 & 122 & 615 & 488 & 123 & 611 & - & - & - \\
\hline
\end{tabular}

Kommentar: Frågan som ställdes var: "I vilken grad anser du att du genom kommunpolitiken kan få igenom en sakfråga?"

Tabellen visar förändringen i procentenheter mellan enkätomgång 1 och 3, där svarsalternativen "hög grad" plus "ganska hög grad", respektive "låg grad" plus "ganska låg grad", har slagits samman. Av dem som var nya inför valet 2014, svarar alltså drygt 16 procentenheter färre att de instämmer till hög/ganska hög grad med påståendet. Det indikerar ett relativt stort fall i tilltron till att få igenom sakfrågor bland de nya efter cirka en halv mandatperiod i kommunpolitiken. Men, notera nu också att tappet i tilltro faktiskt är ännu större bland de som hade kommunpolitisk erfarenhet redan före valet 2014. Där svarar omkring 17 procentenheter färre att de tror att de i hög eller ganska hög grad ska få igenom en sakfråga. I hela undersökningspopulationen som helhet ser vi sålunda att knappt 17 procentenheter färre tror att de ska få igenom en sakfråga halvvägs in i mandatperioden. Generellt sett trycks alltså det politiska självförtroendet ned, om det mäts på detta sätt.

Tabell 2: Tilltro att göra kommunen bättre?

\begin{tabular}{|c|c|c|c|c|c|c|c|c|c|}
\hline \multirow{3}{*}{$\begin{array}{l}\text { Bidra till } \\
\text { att göra } \\
\text { kommunen } \\
\text { bättre? }\end{array}$} & \multirow{2}{*}{\multicolumn{3}{|c|}{$\begin{array}{l}\text { Omgång } 1 \\
\text { Ny i } \\
\text { politiken? }\end{array}$}} & \multirow{2}{*}{\multicolumn{3}{|c|}{$\begin{array}{l}\text { Omgång } 3 \\
\text { Ny i } \\
\text { politiken? }\end{array}$}} & \multirow{2}{*}{\multicolumn{3}{|c|}{$\begin{array}{l}\text { Förändring } \\
\text { Ny i } \\
\text { politiken? }\end{array}$}} \\
\hline & & & & & & & & & \\
\hline & Nej & $\mathrm{Ja}$ & Totalt & $\mathrm{Nej}$ & $\mathrm{Ja}$ & Totalt & Nej & $\mathrm{Ja}$ & Totalt \\
\hline $\begin{array}{l}\text { Hög/ganska } \\
\text { hög grad }\end{array}$ & 86,1 & 80,6 & 84,9 & 71,3 & 61,1 & 69,2 & $-14,8$ & $-19,5$ & $-15,7$ \\
\hline $\begin{array}{l}\text { Låg/ganska } \\
\text { låg grad }\end{array}$ & 13 & 17,8 & 14 & 28,7 & 37,5 & 30,5 & 15,7 & 19,7 & 16,5 \\
\hline Vet ej & 0,9 & 1,5 & 1,1 & 0,1 & 1,4 & 0,4 & $-0,8$ & $-0,1$ & $-0,7$ \\
\hline Totalt & 100 & 100 & 100 & 100 & 100 & 100 & - & - & - \\
\hline Antal obs. & 492 & 123 & 615 & 492 & 123 & 615 & - & - & - \\
\hline
\end{tabular}

Kommentar: Frågan som ställdes var: "I vilken grad anser du att du genom kommunpolitiken kan bidra till att göra kommunen bättre?" 
Ett annat sätt att försöka närma sig frågan om politiskt självförtroende, är att fråga om respondenterna tror att de genom kommunpolitiken kan bidra till att göra kommunen bättre. Förändringen mellan de två svarstillfällena återfinns i tabell 2.

Också det här sättet att försöka fånga respondenternas politiska självförtroende ger ett negativt utfall. Bland de som var nya inför valet 2014, svarar drygt 19 procentenheter färre att de till en hög eller ganska hög grad tror att de kan göra kommunen bättre när de haft omkring två års politisk erfarenhet. Och återigen är detta inget unikt för de nya utan vi ser en negativ förändring bland de mer kommunpolitikerna erfarna: nästan 15 procentenheter färre väljer dessa alternativ ungefär halvvägs in i mandatperioden.

Tabell 3a och 3b: Tilltro att få igenom argument och åsikter i partigrupp och fullmäktige?

\begin{tabular}{|c|c|c|c|c|c|c|c|c|c|}
\hline \multirow{3}{*}{$\begin{array}{l}\text { Få genomslag } \\
\text { för egna } \\
\text { argument/åsikter } \\
\text { i egna } \\
\text { partigruppen? }\end{array}$} & \multirow{2}{*}{\multicolumn{3}{|c|}{$\begin{array}{l}\text { Omgång } 1 \\
\text { Ny i } \\
\text { politiken? }\end{array}$}} & \multirow{2}{*}{\multicolumn{3}{|c|}{$\begin{array}{l}\text { Omgång } 3 \\
\text { Ny i } \\
\text { politiken? }\end{array}$}} & \multirow{2}{*}{\multicolumn{3}{|c|}{$\begin{array}{l}\text { Förändring } \\
\text { Ny i } \\
\text { politiken? }\end{array}$}} \\
\hline & & & & & & & & & \\
\hline & Nej & $\mathrm{Ja}$ & Totalt & Nej & $\mathrm{Ja}$ & Totalt & Nej & $\mathrm{Ja}$ & Totalt \\
\hline $\begin{array}{l}\text { Hög/ganska } \\
\text { hög grad }\end{array}$ & 93 & 83,2 & 91 & 83,7 & 86,5 & 84,2 & $-9,3$ & 3,3 & $-6,8$ \\
\hline $\begin{array}{l}\text { Låg/ganska } \\
\text { låg grad }\end{array}$ & 6,3 & 14,3 & 8 & 16,2 & 13,2 & 15,6 & 9,9 & $-1,1$ & 7,6 \\
\hline Vet ej & 0,8 & 2,5 & 1,1 & 0,1 & 0,3 & 0,2 & $-0,7$ & $-2,2$ & $-0,9$ \\
\hline Totalt & 100 & 100 & 100 & 100 & 100 & 100 & - & - & - \\
\hline Antal obs. & 490 & 123 & 613 & 492 & 124 & 616 & - & - & - \\
\hline \multirow{3}{*}{$\begin{array}{l}\text { Få genomslag } \\
\text { för egna } \\
\text { argument/åsikter } \\
\text { i fullmäktige? }\end{array}$} & \multirow{2}{*}{\multicolumn{3}{|c|}{$\begin{array}{l}\text { Omgång } 1 \\
\text { Ny i } \\
\text { politiken? }\end{array}$}} & \multirow{2}{*}{\multicolumn{3}{|c|}{$\begin{array}{l}\text { Omgång } 3 \\
\text { Ny i } \\
\text { politiken? }\end{array}$}} & \multirow{2}{*}{\multicolumn{3}{|c|}{$\begin{array}{l}\text { Förändring } \\
\text { Ny i } \\
\text { politiken? }\end{array}$}} \\
\hline & & & & & & & & & \\
\hline & Nej & $\mathrm{Ja}$ & Totalt & Nej & $\mathrm{Ja}$ & Totalt & $\mathrm{Nej}$ & $\mathrm{Ja}$ & Totalt \\
\hline $\begin{array}{l}\text { Hög/ganska } \\
\text { hög grad }\end{array}$ & 59,2 & 47,9 & 56,9 & 41,5 & 25,3 & 38,1 & $-17,7$ & $-22,6$ & $-18,8$ \\
\hline $\begin{array}{l}\text { Låg/ganska } \\
\text { låg grad }\end{array}$ & 38 & 45,9 & 39,7 & 52,9 & 66,5 & 55,8 & 14,9 & 20,6 & 16,1 \\
\hline Vet ej & 2,8 & 6,1 & 3,5 & 5,6 & 8,2 & 6,2 & 2,8 & 2,1 & 2,7 \\
\hline Totalt & 100 & 100 & 100 & 100 & 100 & 100 & - & - & - \\
\hline Antal obs. & 488 & 123 & 611 & 484 & 123 & 607 & - & - & - \\
\hline
\end{tabular}

Kommentar: Frågorna som ställdes var: "I vilken grad anser du att du genom kommunpolitiken kan få genomslag för egna argument/åsikter i egna partigruppen?" (3a, övre tabellen), samt "I vilken grad anser du att du genom kommunpolitiken kan få genomslag för egna argument/åsikter i fullmäktige?” (3b, nedre tabellen).

Att få igenom sakfrågor och påverka kommunen till att bli en bättre plats skulle kunna ses som att sätta ribban rätt så högt vad avser tilltro till egen förmåga att påverka politiken. Därför har vi 
också ställt frågor om kanske något mer vardagsnära, återkommande saker som rör det politiska engagemanget: tilltron till att få igenom argument och åsikter i den egna partigruppen, liksom i fullmäktige. Resultaten redovisas i tabell 3.

Tabell 3 visar en liten ökning i självförtroende hos de som är nya i politiken ur en bestämd aspekt: något fler (drygt 3 procentenheter, för att vara precis) svarar att de $\mathrm{i}$ hög eller ganska hög grad tror att de får genomslag för egna argument/åsikter $i$ partigruppen när enkätomgång 1 och 3 jämförs. För samma fråga ser vi emellertid ett tapp bland de mer erfarna: drygt 9 procentenheter färre väljer de alternativen.

Riktar vi så blickarna mot tilltron att få genomslag för argument/åsikter i fullmäktige, återser vi emellertid det generella tappet i politiskt självförtroende som vi noterade i tabellerna 1 och 2 . Närmare 23 procentenheter färre väljer hög/ganska hög grad-alternativet bland de nya politikerna, och cirka 18 procentenheter färre bland de mer erfarna.

I tabell 4 och 5 redovisas svar på frågor som inte på något direkt sätt kan sägas mäta politiskt självförtroende. De handlar snarare om huruvida politikernas initiala förhoppningar om att lära sig någonting, till exempel få insikter $\mathrm{i}$ den lokala politiken samt att få delta $\mathrm{i}$ intressanta diskussioner, infrias eller kommer på skam. Resultaten återfinns här nedan.

Tabell 4: Tilltron att få insikt i den lokala politiken?

\begin{tabular}{|c|c|c|c|c|c|c|c|c|c|}
\hline \multirow{3}{*}{$\begin{array}{l}\text { Få } \\
\text { insikt/inblick } \\
\text { i den lokala } \\
\text { politiken? }\end{array}$} & \multirow{2}{*}{\multicolumn{3}{|c|}{$\begin{array}{l}\text { Omgång } 1 \\
\text { Ny i } \\
\text { politiken? }\end{array}$}} & \multirow{2}{*}{\multicolumn{3}{|c|}{$\begin{array}{l}\text { Omgång } 3 \\
\text { Ny i } \\
\text { politiken? }\end{array}$}} & \multirow{2}{*}{\multicolumn{3}{|c|}{$\begin{array}{l}\text { Förändring } \\
\text { Ny i } \\
\text { politiken? }\end{array}$}} \\
\hline & & & & & & & & & \\
\hline & Nej & $\mathrm{Ja}$ & Totalt & Nej & $\mathrm{Ja}$ & Totalt & Nej & $\mathrm{Ja}$ & Totalt \\
\hline $\begin{array}{l}\text { Hög/ganska } \\
\text { hög grad }\end{array}$ & 97,1 & 96,3 & 96,9 & 94,5 & 94,7 & 94,5 & $-2,6$ & $-1,6$ & $-2,4$ \\
\hline $\begin{array}{l}\text { Låg/ganska } \\
\text { låg grad }\end{array}$ & 2,7 & 3,7 & 2,9 & 5,5 & 4,5 & 5,3 & 2,8 & 0,8 & 2,4 \\
\hline Vet ej & 0,1 & 0 & 0,1 & 0 & 0,8 & 0,2 & $-0,1$ & 0,8 & 0,1 \\
\hline Totalt & 100 & 100 & 100 & 100 & 100 & 100 & - & - & - \\
\hline Antal obs. & 491 & 124 & 615 & 487 & 122 & 609 & - & - & - \\
\hline
\end{tabular}

Kommentar: Frågan som ställdes var: "I vilken grad anser du att du genom kommunpolitiken kan få insikt/inblick i den lokala politiken?" 
Tabell 5: Tilltro att få delta i intressanta diskussioner?

\begin{tabular}{|c|c|c|c|c|c|c|c|c|c|}
\hline \multirow[t]{2}{*}{$\begin{array}{l}\text { Få delta i } \\
\text { intressanta } \\
\text { diskussioner? }\end{array}$} & \multicolumn{3}{|c|}{$\begin{array}{l}\text { Omgång } 1 \\
\text { Ny i } \\
\text { politiken }\end{array}$} & \multicolumn{3}{|c|}{$\begin{array}{l}\text { Omgång } 3 \\
\text { Ny i } \\
\text { politiken }\end{array}$} & \multicolumn{3}{|c|}{$\begin{array}{l}\text { Förändring } \\
\text { Ny i politiken }\end{array}$} \\
\hline & $\mathrm{Nej}$ & $\mathrm{Ja}$ & Totalt & Nej & $\mathrm{Ja}$ & Totalt & $\mathrm{Nej}$ & $\mathrm{Ja}$ & Totalt \\
\hline $\begin{array}{l}\text { Hög/ganska } \\
\text { hög grad }\end{array}$ & 92,3 & 90,4 & 91,9 & 88,5 & 78,8 & 86,5 & $-3,8$ & $-11,6$ & $-5,4$ \\
\hline $\begin{array}{l}\text { Låg/ganska } \\
\text { låg grad }\end{array}$ & 7,4 & 8,1 & 7,5 & 11,4 & 20,9 & 13,4 & 4 & 12,8 & 5,9 \\
\hline Vet ej & 0,4 & 1,5 & 0,6 & 0 & 0,3 & 0,1 & $-0,4$ & $-1,2$ & $-0,5$ \\
\hline Totalt & 100 & 100 & 100 & 100 & 100 & 100 & - & - & - \\
\hline Antal obs. & 485 & 121 & 606 & 490 & 122 & 612 & - & - & - \\
\hline
\end{tabular}

Kommentar: Frågan som ställdes var: "I vilken grad anser du att du genom kommunpolitiken kan få delta i intressanta diskussioner?"

Trots en något vagare koppling till självförtroendebegreppet (såsom vi här förstår det), har vi valt att redovisa dessa resultat för att i syfte att understryka den allmänna och generella bilden av icke-infriade förväntningar och till synes allt mer desillusionerade respondenter: ungefär halvvägs in i mandatperioden uppger sammanlagt drygt 2 procentenheter färre att de tror att de ska få insikt/inblick i den lokala politiken (små skillnader mellan erfarna och nya politiker), och drygt 5 procentenheter färre att de ska få delta i intressanta diskussioner. För den senare frågan är de minskade förhoppningar kraftigt mycket mer uttalat hos de som var nya i politiken - här är det nästan 12 procentenheter färre som tror att de ska få delta i intressanta diskussioner när halva mandatperioden har gått.

Vad kan då sägas? Våra data får sägas vara tämligen entydiga, sett till den övergripande frågeställningen: det politiska självförtroendet stärks i vart fall inte. Snarare pekar flera av våra resultat i riktning mot att det politiska självförtroendet hos våra respondenter försvagas; något som går på emot med de initiala deltagarteoretiska förväntningarna. En bild framträder av politiker som över hela linjen får sägas bli något mer desillusionerade ju längre mandatperioden går. Detta gäller alltså inte enbart de nya politikerna. En tilltagande, ska vi kanske kalla det cynism, breder ut sig också bland de mer erfarna. Det enda egentliga undantaget från den generella bilden, är att något fler nya politiker (drygt 3 procentenheter), tror sig få gehör för åsikter och argument i den egna partigruppen efter att ha erfarit cirka en halv mandatperiod.

\section{Ideal kontra verklighet: ändrad uppfattning om maktförhållanden och demokrati?}

Detta om synen på det egna politiska självförtroendet. Hur påverkas då synen på hur demokratin i kommunpolitiken uppfattas av våra respondenter? Den teoretiska förutsägelsen är, som sagt, att tilltron till demokratins procedurer och institutioner stärks av deltagandet (t.ex. Finkel 1987). Vi har ställt tre frågor som syftar till att försöka komma åt svaret på den frågan. Hur påverkas: 1) synen på vem/vilka/vad som har inflytande över det kommunala beslutsfattandet?; 2) synen 
på hur utbredd den lokala korruptionen är?; och 3) synen på hur nöjd man är med hur den lokala demokratin fungerar?

I enkätomgångarna har vi intresserat oss för vem eller vilka våra respondenter anser har makten i kommunen. Vi har gjort detta genom ställa frågan: "Hur stort inflytande anser eller tror du att följande aktörer har över beslutsfattandet i allmänhet i din kommun?", och därefter har vi listat kommunstyrelsens ordförande, kommunstyrelsen, kommunfullmäktige, nämnderna, de lokala partiorganisationerna, tjänstemännen, det lokala näringslivet och medborgarna. Av jämförelserna mellan enkätomgång 1 och 3, framgår att processen av att erfara ungefär en halv mandatperiod gör att synen på vem som har inflytande över det kommunala beslutsfattandet justeras en del (dessa resultat visas av utrymmesskäl ej i tabellform, men kan vid förfrågan förmedlas av författarna). Överlag ser vi hur det finns en hygglig samsyn på att i princip alla aktörer har mindre makt efter omkring halva mandatperioden. Mellan erfarna och nya ser vi den mest uttalade skillnaden i synen på nämnderna, där de erfarna inte ändrar sin uppfattning särskilt mycket, medan nästan 16 procentenheter färre av dem som saknade erfarenhet innan valet 2014 svarar att nämnderna i hög eller mycket hög grad har inflytande. Den enda aktörskategori som uppfattas ha mer inflytande i enkätomgång 3, är de icke-valda tjänstemännen. Det är för övrigt en grupp som respondenterna inte alls tycker bör ha särskilt mycket inflytande.

Tabell 6: Ändras synen på hur utbredd den lokala korruptionen är?

\begin{tabular}{|c|c|c|c|c|c|c|c|c|c|}
\hline \multirow{3}{*}{$\begin{array}{l}\text { Hur ofta } \\
\text { förekommer } \\
\text { oegentligheter? }\end{array}$} & \multirow{2}{*}{\multicolumn{3}{|c|}{$\begin{array}{l}\text { Omgång 1 } \\
\text { Ny i } \\
\text { politiken? }\end{array}$}} & \multirow{2}{*}{\multicolumn{3}{|c|}{$\begin{array}{l}\text { Omgång } 3 \\
\text { Ny i } \\
\text { politiken? }\end{array}$}} & \multirow{2}{*}{\multicolumn{3}{|c|}{$\begin{array}{l}\text { Förändring } \\
\text { Ny i } \\
\text { politiken? }\end{array}$}} \\
\hline & & & & & & & & & \\
\hline & Nej & $\mathrm{Ja}$ & Totalt & Nej & $\mathrm{Ja}$ & Totalt & Nej & $\mathrm{Ja}$ & Totalt \\
\hline $\begin{array}{l}\text { Aldrig/mycket/ } \\
\text { ganska sällan }\end{array}$ & 94 & 85 & 92,4 & 97,2 & 86,8 & 95,3 & 3,2 & 1,8 & 2,9 \\
\hline $\begin{array}{l}\text { Ganska/ } \\
\text { mycket ofta }\end{array}$ & 6 & 15 & 7,6 & 2,8 & 13,2 & 4,7 & $-3,2$ & $-1,8$ & $-2,9$ \\
\hline Totalt & 100 & 100 & 100 & 100 & 100 & 100 & - & - & - \\
\hline Antal obs. & 434 & 91 & 525 & 492 & 96 & 588 & - & - & - \\
\hline
\end{tabular}

Kommentar: Frågan som ställdes var: "Hur ofta tror du att andra politiker och tjänstemän i din kommun blir erbjudna pengar eller annan förmån, för att fatta ett beslut som gynnar den/de som erbjudit sådan ersättning?"

En fråga som inte rör maktfördelning utan mer direkt rör demokratins procedurer - framför allt hur rättssäkert, neutralt och opartiskt systemet fungerar - rör uppfattningar om förekomsten av korruption. I enkäten ställde vi frågan om hur ofta man trodde att andra politiker och tjänstemän i hemkommunen blir erbjudna pengar eller annan förmån för att fatta ett beslut som gynnar den/de som erbjudit sådan ersättning. I tabell 6 redovisas förändringen.

Tabellen visar förhållandevis små förändringar. Händer något, är det att fler väljer alternativet att korruption är något som sker väldigt sällan. Med andra ord, bland de nya politikerna tycks 
erfarenheten göra att tilltron till rättssäkerheten i den egna kommunen, om något, ökar marginellt. Detta gäller emellertid i lika hög, till och med lite högre grad, för de mer erfarna politikerna.

Slutligen ställde vi en fråga om respondenterna, på det hela taget, var nöjda med det sätt på vilket demokratin fungerar i deras respektive hemkommuner. Resultatet och förändringen redovisas i tabell 7 .

Tabell 7: Ändras synen på hur väl demokratin fungerar?

\begin{tabular}{llccccccccc}
\hline $\begin{array}{l}\text { Nöjd med } \\
\text { demokratin i } \\
\text { din kommun? }\end{array}$ & $\begin{array}{l}\text { Omgång 1 } \\
\text { Ny i } \\
\text { politiken }\end{array}$ & \multicolumn{3}{c}{$\begin{array}{l}\text { Omgång 3 } \\
\text { Ny i } \\
\text { politiken }\end{array}$} & \multicolumn{5}{c}{$\begin{array}{l}\text { Förändring } \\
\text { Ny i } \\
\text { politiken }\end{array}$} \\
& Nej & Ja & Totalt & Nej & Ja & Totalt & Nej & Ja & Totalt \\
Mycket/ganska & 73,7 & 58,5 & 70,5 & 73,3 & 59 & 70,3 & $-0,4$ & 0,5 & $-0,2$ \\
$\begin{array}{l}\text { Inte särskilt/ } \\
\text { inte alls }\end{array}$ & 26,1 & 41,5 & 29,3 & 26,7 & 40,5 & 29,6 & 0,6 & -1 & 0,3 \\
$\begin{array}{l}\text { Ingen } \\
\text { uppfattning }\end{array}$ & 0,1 & 0 & 0,1 & 0 & 0,5 & 0,1 & $-0,1$ & 0,5 & 0 \\
Totalt & 100 & 100 & 100 & 100 & 100 & 100 & - & - & - \\
Antal obs. & 492 & 124 & 616 & 494 & 124 & 618 & - & - & - \\
\hline
\end{tabular}

Kommentar: Frågan som ställdes var: "På det hela taget, hur nöjd är du med det sätt på vilket demokratin fungerar på följande nivåer?"

Precis som med korruptionsfrågan, ser vi mycket små förändringar. En halv mandatperiods erfarenhet av att vara förtroendevald i kommunpolitiken påverkar inte synen på hur demokratin fungerar i vare sig positiv eller negativ riktning. I sig är robustheten i uppfattningarna om hur nöjd man är med demokratin ganska intressant, särskilt sett till övriga förändringar vi redovisat. Det politiska självförtroendet försämras i en rad avseenden sett till synen på ens egen förmåga att påverka/få genomslag och man anser att många av de folkvalda aktörerna och institutionerna har mindre makt/inflytande än man trodde innan valet; men trots allt förändras inte nöjdheten med hur demokratin fungerar.

\section{Påverkas synen på den egna representantrollen?}

Slutligen, en fråga som egentligen vare sig handlar om politiskt självförtroende eller tilltron till demokratins institutioner och procedurer utan är mer kopplad till den egna demokratisynen. I boken Kommunpolitiker i den stora nyordningens tid beskriver Bäck (2000), tre olika representationsstilar som en politiker kan välja att anamma. För det första kan de inta en förtroendemannaroll där politikern anser sig ha fått ett mandat att förvalta efter eget omdöme (dvs. man representerar "sig själv"). För det andra kan hon eller han ta på sig en väljardelegatroll där man anser sig ha ett bundet mandat av väljaren och skyldighet att följa väljaropinioner (dvs. man representerar sina väljare). För det tredje återfinns en representationsstil som kallas partiombudsmannen, en stil där politikern främst ser sig som 
ansvarig mot det egna partiet. Så frågan är: gör själva processen att vara förtroendevald under några år något med synen på den egna representantrollen? Tabell 8 visar förändringarna.

Tabell 8: Ändras synen på vem man representerar?

\begin{tabular}{|c|c|c|c|c|c|c|c|c|c|}
\hline \multirow{2}{*}{$\begin{array}{l}\text { Vem/vilka } \\
\text { man } \\
\text { representerar } \\
\text { som } \\
\text { politiker? }\end{array}$} & \multicolumn{3}{|c|}{$\begin{array}{l}\text { Omgång } 1 \\
\text { Ny i } \\
\text { politiken }\end{array}$} & \multicolumn{3}{|c|}{$\begin{array}{l}\text { Omgång } 3 \\
\text { Ny i } \\
\text { politiken }\end{array}$} & \multicolumn{3}{|c|}{$\begin{array}{l}\text { Förändring } \\
\text { Ny i politiken }\end{array}$} \\
\hline & Nej & $\mathrm{Ja}$ & Totalt & Nej & $\mathrm{Ja}$ & Totalt & Nej & $\mathrm{Ja}$ & Totalt \\
\hline Sitt parti & 29,6 & 30,5 & 29,8 & 38,1 & 37,3 & 37,9 & 8,5 & 6,8 & 8,1 \\
\hline $\begin{array}{l}\text { Sina } \\
\text { personliga } \\
\text { övertygelser }\end{array}$ & 8,9 & 10,2 & 9,2 & 5,3 & 5 & 5,3 & $-3,6$ & $-5,2$ & $-3,9$ \\
\hline Väljarna & 61,5 & 59,4 & 61 & 56,6 & 57,7 & 56,8 & $-4,9$ & $-1,7$ & $-4,2$ \\
\hline Totalt & 100 & 100 & 100 & 100 & 100 & 100 & - & - & - \\
\hline Antal obs. & 491 & 124 & 615 & 491 & 124 & 615 & - & - & - \\
\hline
\end{tabular}

Kommentar: Frågan som ställdes var: "Det finns många olika sätt att representera sina väljare. Markera det alternativ som stämmer bäst med hur du ser på rollen som folkvald. En folkvald är i första hand en företrädare för..." (därefter fick respondenten kryssa för något av de tre alternativen).

Intressant nog verkar cirka en halv mandatperiod göra något med synen på sig själv som politiker. Under mandatperioden tycks man socialiseras in $\mathrm{i}$ att bli allt mer av en partiombudsman än vad man var innan valet. Denna iakttagelse går i linje med resultat som återfinns i till exempel Bäck (2000) och Fredriksson (2003). Men, värt att uppmärksamma är månne att detta lite överraskande gäller både de mer erfarna och de nyare politikerna. Möjligen är det något mer på gång här, än en socialisering av just nya politiker. Vi kanske ser ett slags valårseffekt, där alla politiker - oavsett om de är nya eller erfarna - ser sig som lite friare och mer väljarorienterade strax innan ett val. Men halvvägs in i mandatperioden, är man så inne $\mathrm{i}$ den politiska vardagen och det politiska arbetet att man kommit att vänja sig vid att inordna sig partilinjen; och att detta förklarar skillnaderna mellan mätpunkt 1 och 3.

\section{Slutdiskussion}

Som Finkel (1987: 441) konstaterar, finns en föreställning inom deltagardemokratisk litteratur att politiskt deltagande är något gott i sig självt, eftersom det har potentialen att stärka "political self-competence, and satisfaction with decision-making structures". I denna uppsats har vi, möjligen oortodoxt, argumenterat för att ett potentiellt lovande sätt att studera denna förutsägelse är att rikta strålkastarljuset mot individer som för första gången får ett förtroendeuppdrag i svensk kommunpolitik, och därefter analysera hur politiskt självförtroende, syn på demokrati och egen representantroll påverkas av omkring två års politiskt deltagande som är tämligen långsiktigt och kräver i typfallet brett ansvarstagande. Det precisa syftet med uppsatsen har därmed varit att undersöka vad erfarenheten av att bli invald i 
kommunfullmäktige, och under ett par år vara en del av den politiska verkligheten som förtroendevald, gör med det politiska självförtroendet och tilliten till demokratin i hemkommunen.

Sett till teorins prediktioner, får resultatet sägas vara nedslående. Det politiska självförtroendet stärks inte av att bli förtroendevald och leva med den politiska erfarenheten av att fungera som förtroendevald under en halv mandatperiod. Tvärtom, snarare. Med ett enda undantag, oavsett hur vi har ställt frågor om saken, tycks det sjunka. Detta hade möjligen kunnat förklaras med naivitet och aningslöshet om uppdragets krav och karaktär från nybörjarnas sida; eller en växande insikt om politikens komplexitet i denna kategori av politiker. Men, vad som är något förbryllande och som gör resultaten tämligen svårtolkade, är att den minskade tilltron till sig själv inte är förbehållen de nya. Den återkommer, och är i vissa fall något mer uttalad, hos de relativt mer erfarna politikerna. Vi saknar möjligheter att på något djupgående sätt förklara detta generella fall i självförtroendet i hela vårt urval, men åtminstone två - ej ömsesidigt uteslutande utan sannolikt ömsesidigt förstärkande - hypoteser aktualiseras.

Den första hypotesen har att göra med att det är välbelagt att det åtminstone i befolkningen som helhet finns ett slags "valårseffekt" i svensk politik (t.ex. Holmberg och Weibull 2015). Under valår stiger förtroendet för allehanda politiska fenomen: medborgarna uppskattar partier mer, samtidigt som de politiska institutionerna värderas högre. Måhända finns också en valårseffekt avseende politiskt självförtroende; att alla respondenter - vare sig de är nya eller erfarna - gör litet för optimistiska glädjekalkyler i den allmänna valrörelseeuforin, förhoppningar som sedan generellt tonas ned när den politiska vardagen sätter in under de två första åren av mandatperioden? Detta skulle i så fall kunna begripliggöra att vi ser ett allmänt tapp i politiskt självförtroende, både hos nya och mer erfarna kommunpolitiker. I linje med en sådan inramning av resultaten, kanske förtroendetappet mellan just 2014 och 2016 är extra begripligt. Ser vi till SOM-institutets siffror, är nämligen det generella förtroendetappet för politiska institutioner mellan 2014 till 2015 det största som uppmätts från ett år till ett annat sedan mitten på 1990talet (Oscarsson och Bergström 2016: 7). Hypotesen om en sådan "cykeleffekt" i politiskt självförtroende kan emellertid prövas först när vi samlat in svar från vår panel också månaderna innan valet 2018.

Den andra hypotesen har att göra med att respondenterna, under en valrörelse, inte kan veta om de kommer att tillhöra majoritetspartierna i kommunen. De vet inte heller om de kommer att få de poster/förtroendeuppdrag de allra mest hoppas att få. När de besvarade vår första enkät, alltså före 2014 års val, är det inte ett helt omöjligt antagande att många dels såg framför sig att de skulle hamna i majoritet $\mathrm{i}$ hemkommunen, dels att de skulle få det förtroendeuppdrag de mest av allt hoppades att få. Ifall en, eller båda, av dessa förhoppningar kommit på skam, är det inte märkligt att vi ser ett generellt tapp i politiskt självförtroende i vår undersökningspopulation. I Erlingsson och Öhrvall (2017) har vi gjort några tentativa analyser av denna hypotes. Där försökte vi se om det tappade förtroendet på något sätt hänger samman med om man är missnöjd med vilka poster i kommunen man sedermera fick. Om den hjälphypotesen används för att begripliggöra tappat självförtroende, får den preliminärt ett litet stöd. Bland dem som var 
mycket nöjda med sina uppdrag sjönk tron på egna förmågan mindre än bland övriga, och i vissa avseenden inte alls. Men, och detta är centralt för vad vi undersöker i denna uppsats, det politiska självförtroendet ökar inte i gruppen av i detta avseende mycket nöjda respondenter. Så, åtminstone i dessa preliminära analyser, kan hjälphypotesen inte riktigt rädda föreställningen om deltagandets positiva spiral.

I övrigt såg vi att tilliten till hur demokratin fungerar i stort sett såg likadant ut före valet som halvvägs in i mandatperioden. Robustheten i synen på demokratin är principiellt intressant. Det ska dels läsas i ljuset av det allmänt försvagade politiska självförtroendet hos respondenterna, dels i ljuset av en allmän förändring i tron om var makten i hemkommunen är placerad (alla folkvalda aktörer/institutioner ansågs ha mindre inflytande halvvägs in i mandatperioden, medan tjänstemännens makt ansågs vara större och betydligt starkare än vad våra respondenter ansåg att de borde ha). Här saknar vi i allt väsentligt goda kandidater till förklaringar varför vi ser det vi ser. Gissningsvis är det något annat och något mer djupliggande än det egna politiska självförtroendet, eller synen på hur makten är fördelad i hemkommunen, som styr hur nöjd man är med demokratin. Vad detta "något annat" är kan vi emellertid inte säga något om i denna studie.

Slutligen är det värt att uppmärksamma att vi i enkätomgång 1, innan valet, inte såg några nämnvärda skillnader i synen på representationsrollen mellan nya och mer erfarna politiker. I båda grupperna var det runt 30 procent som ansåg att man i första hand representerade sitt parti, cirka 60 procent att man representerade sina väljare och omkring 10 procent sig själv. Men, knappt två år senare ser vi en signifikant ökning av respondenter som identifierar sig som "partiombudsmän": nästan 8 procentenheter fler ser sig i första hand som representanter för partiet, på bekostnad av att i första hand representera sig själv eller väljarna. Det tycks alltså med tiden, under mandatperiodens lopp, sålunda ske en viss rättning i partiledet både bland nya och mer erfarna kommunpolitiker. Kanske är detta en naturlig valårscykel. Inför ett val upplever man sig måhända som lite friare i förhållande till partiet, liksom att man har en mer naturlig väljarkontakt. Halvvägs in i mandatperioden är man djupt inne i den politiska vardagslunken, och har säkert mer än ett par gånger blivit påmind om vikten av partidisciplin i fullmäktige. Mekanismerna bakom tilltagande partilojalitet ju längre mandatperioden går, är avgjort ett intressant forskningsområde i behov av fördjupade studier i framtiden.

Ur demokratisk synvinkel är resultatet - att fler kommunpolitiker under en mandatperiod socialiseras in i rollen som partiombudsman - knappast trivialt. Som Karlsson och Gilljam (2014: 292) slår fast, liknar idealet om att vara "väljardelegat" och "partiombudsman" varandra. Båda bygger på idén om att den förtroendevalde har ett bundet mandat från väljarna. Men i lägen då partiets linje skiljer sig från väljarnas uppfattningar, understryks skillnaderna mellan de båda principerna. Att följa partilinjen, snarare än väljarlinjen, kan därför få långtgående politiska konsekvenser, inte minst i kommuner där vi ser ett uppsving i olika typer av medborgarinitiativ som går på tvärs mot fullmäktiges vilja. 


\section{Författarnas tack}

Författarna vill rikta ett tack till Patrik Jarelius Persson, som varit forskningsassistent i projektet och administrerat enkätutskicket som uppsatsen bygger på. Stort tack också för konstruktiva synpunkter från deltagarna i arbetsgruppen Political Parties and Political Behavior vid Statsvetenskapliga förbundets årsmöte i Visby, 19-21 oktober 2016.

\section{Noter}

${ }^{1}$ I litteraturen brukar political efficacy - brett och något förenklat - definieras som tilltron till demokratins institutioner och procedurer liksom att medborgarna själva anser sig förstå det politiska systemet samt har tilltro till att de kan påverka politiken.

${ }^{2}$ Med demokratiexperiment avses olika varianter av brukar- och medborgarinflytande som sätts upp vid sidan av de formella representativa organen. Exempel på sådana demokratisatsningar är förstärkning av folkomröstningsinstitutet, brukarmedverkan och brukarinflytande, byalag, olika slags rådsorgan och medborgerlig initiativrätt i fullmäktige (Gilljam och Jodal 2005: 1)

\section{Referenser}

Bäck, H. (2000) Kommunpolitiker i den stora nyordningens tid. Malmö: Liber.

Erlingsson, G. Ó. och R. Öhrvall (2010) Politikens villkor: Om engagemang och avhopp $i$ kommunpolitiken. Linköping: Centrum för kommunstrategiska studier.

Erlingsson, G. Ó. och R. Öhrvall (2017) Fullmäktigeledamoten och mandatperioden. Stockholm: Sveriges kommuner och landsting.

Erlingsson, G. Ó., M. Persson och R. Öhrvall (2012) "Den motvilligt engagerade altruisten: Om partimedlemskap och partiaktivism", Statsvetenskaplig tidskrift 114(2):185-205.

Erlingsson, G. Ó., M. Fogelgren och R. Öhrvall, (2015) Att ta plats i politiken. Stockholm: Sveriges kommuner och landsting.

Finkel, S. E. (1987) "The Effects of Participation on Political Efficacy and Political Support: Evidence from a West German Panel", The Journal of Politics 49(2):441-464.

Fredriksson, J. (2001) "Vägen till politiken. En etnologisk studie av hur det går till när man blir kommunalpolitiskt engagerad", i SOU 2001:48 Att vara med på riktigt. Demokratiutveckling $i$ kommuner och landsting. Stockholm: Fritzes.

Fredriksson, J. (2003) Politisk kultur och samhällsengagemang. En etnologisk studie av den parlamentariska vardagen. Stockholm: Carlsson bokförlag.

Gilljam, M. och O. Jodal (2005) Kommunala demokratisatsningar: vägen till en mer vital demokrati? Göteborg: Göteborgs universitet, CEFOS. 
Hassis, L., H. Kåks och J. Söderfeldt (2009) Unga politiker i Dalarna. Varför hoppar de av och vad kan få dem att stanna kvar i politiken? Falun: Dalarnas forskningsråd.

Holmberg, S. och L. Weibull (2015) "Demokratins haloeffekt", i Bergström, A., B. Johansson, H. Oscarsson och M Oskarson (red.) Fragment. Göteborg: Göteborgs universitet, SOMinstitutet.

Institutet för lokal och regional demokrati (2006) Att sluta i förtid. Växjö: Institutet för lokal och regional demokrati.

Jacobsson, K. (1999) "Den offentliga demokratisynen”, i SOU 1999:77 Demokrati och medborgarskap. Stockholm: Fritzes.

Jarl, M. (2003) "Deltagardemokraterna och den representativa demokratin", i Gilljam, M. och J. Hermansson (red.) Demokratins mekanismer. Lund: Liber.

Karlsson, D. (2001) "Ny som förtroendevald i kommuner och landsting", i SOU 2001:48 Att vara med på riktigt: Demokratiutveckling $i$ kommuner och landsting. Stockholm: Fritzes.

Karlsson, D. och M. Gilljam (2014) "Partier, representationsprinciper och bilderna av den svenska demokratin", i Karlsson, D. och M. Gilljam (red.) Svenska politiker: Om de folkvalda i riksdag, landsting och kommun. Stockholm: Santérus förlag.

Montin, S. (1998) Lokala demokratiexperiment: Exempel och analyser. Stockholm: Fritzes.

Nielsen, P. (2001) "På och av - om uppdragsvillighet, rekrytering och avhopp i den kommunala demokratin", i SOU 2001:48 Att vara med på riktigt. Stockholm: Fritzes.

Oscarsson, H. och A. Bergström (2016) Svenska trender. Göteborg: Göteborgs universitet, SOM-institutet.

Pateman, C. (1970) Participation and Democratic Theory. Cambridge: Cambridge University Press.

SCB (2015) Förtroendevalda i kommuner och landsting. Stockholm: Statistiska centralbyrån.

Sveriges kommuner och landsting (2005) Makten och möjligheten $i$ kommunpolitiken. Stockholm: Sveriges kommuner och landsting.

SVT (2006-02-13) "Unga och kvinnor hoppar av politiken. Statsvetare: En varningssignal för demokratin". Sveriges television, 13 februari 2006.

SVT (2015-01-13) ”Många avhopp i politiken”. Sveriges television, 13 januari 2015.

Thompson, D. (1970) The Democratic Citizen. Cambridge: Cambridge University Press. 